THE STOLZE GAS TURBINE.

The steady progress made by steam turbines on the one hand and the ever-increasing use of reciprocating gas motors in cases where steam engines were formerly exclusively used, lend particular interest to a gas turbine that has been introduced in Germany.

The gas turbine in question is, strange to say, of no recent date. In fact, it was invented by Dr. Stolze as far back as 1873

We are indebted to the courtesy of the Gasturbinen Gesellschaft Stolze, of Berlin-Char-

lottenburg, for the particulars given below, as well as for the illustration reproduced.

The principle underlying the construction of this turbine consists in compressing atmospheric air to a moderate tension, say one and onehalf atmospheres above atmospheric pressure, and in heating afterward this compresse air so as to cause it to assume a two or two and one-half fold volume, with the same tension, after which the air tension is allowed to drop again to atmospheric pressure.

The excess of work performed over the absorbed energy is thus due to the increase in volume resulting from the heating.

Two sets of turbines of different design are mounte on a common shaft. One of these serves as an air compressor, while the other drives the shaft by means of the heated air Each set consists of several rows of Each set consists of several rows of
guiding vanes, fitte to the engine casing, and of several rows of run ning vanes of a corresponding design, secure to a common rotating cone, which turns with the shaft. One of these turbine systems draws in the fresh air, compressing it to a given tension through a preheater (heate with exhaust gases) and driving the greater part of it into a chamber lined with refractory mate

rial. The smaller part is conveyed beneath the grate of a producer, where it serves to volatilize the fuel. The gas thus formed penetrates into the chamber mentioned, to be burnt there by the compressed air in suitable burners and converted into carbonic acid and water vapor, while evolving large amounts of heat These gases next enter the second turbine system, where they are allowed to expand in traversing the various steps, thus performing useful work.

The process ${ }^{-i s}$ thus analogous to the cycle performed in all combustion engines. A distinguishing feature is, however, that the mixing takes place after compression, and the combustion at constant pressure.

A large-sized engine of an output of 200 effective horse-power is nearing completion in Berlin, and this plant is represented in the accompanying photograph.

\section{THE OLD PORTAGE RAILROAD IN PENNSYLVANIA} BY EDWARD H. L. PAGE.

The recently constructed freight cutoff of the Pennsylvania Railroad Company south of Altoona, Pa.,

for the purpose of relieving the greatly congested freight traffic of that city, has destroyed some of the historic old landmarks of the State, and suggests at this time a sketch of the evolution of transportation during the nineteenth century in the Keystone State.

For some time prior to 1800 , travel across the State had been made in canoes, and in river barges propelled by poles, or along the shores of her ever-winding rivers by horse and foot, and by intervening portages on Indian trails, connecting points on the different rivers. Thus at this time was made the disas.

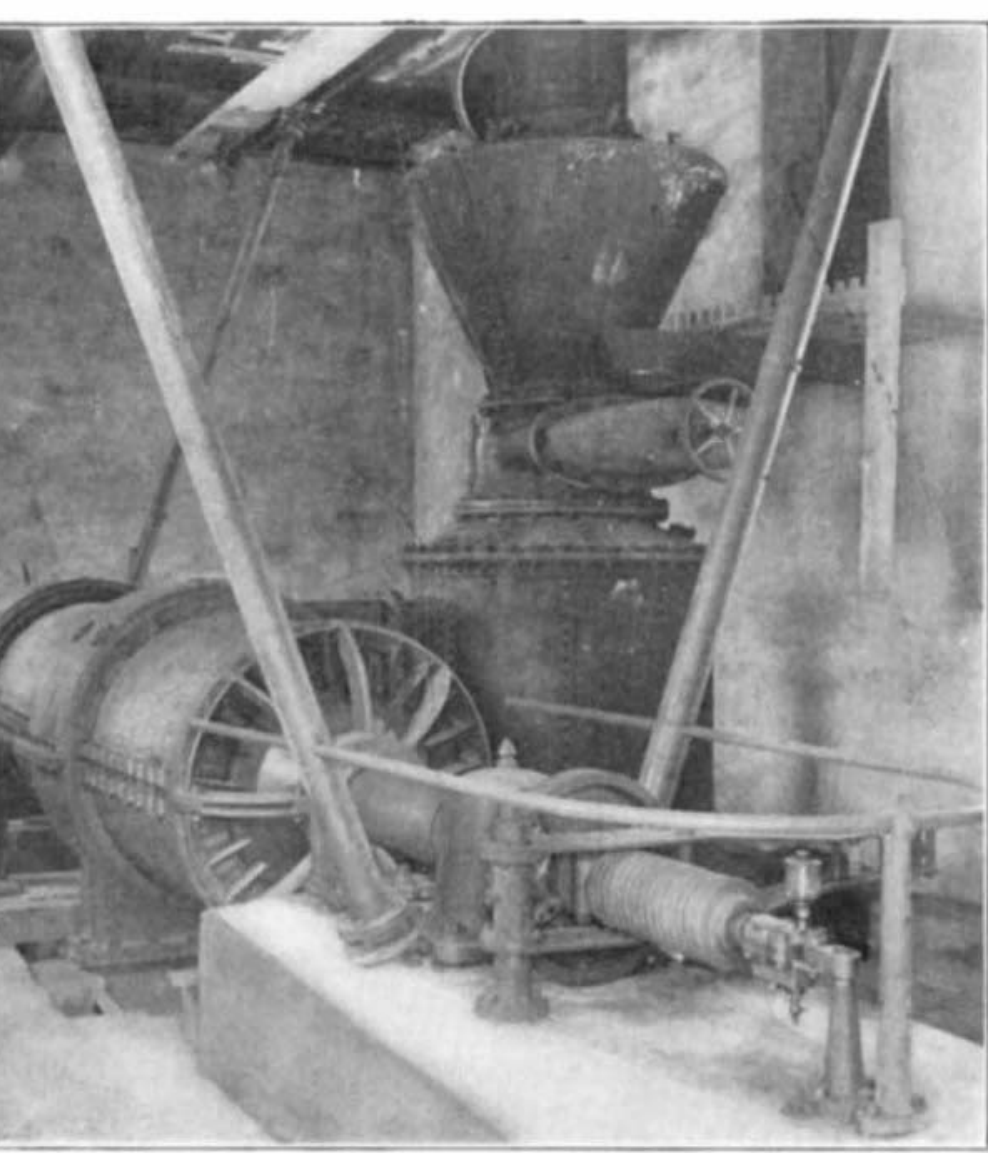

THE STOLZE GAS TURBINE.

second only to the grand old Roman military roads of Great Britain. In 1834 the old Portage Railroad was built from Hollidaysburg to Johnstown, over the Allegheny Mountains, a distance of forty miles, to connect the canals which traverse the State east and west from these points.

The Old Portage Road was constructed from material brought from England. The British government sent over experienced engineers to instruct the Americans in the running of the stationary steam engines used upon the inclined planes of the road. The railroad's highest point was about twenty-seven hundred feet above sea level; being only two hundred feet lowel; being only two hundre feet lowis the highest point of the Allegheny Mountains in Pennsylvania. The road consisted of ten planes, five of which were on either side of the mountain, and intervening levels. In 1835 the canalboats were so constructed that they could be taken in sections and hauled over the mountain on flat cars, without disturbing their cargoes.

The road was governed by a board known as canal commissioners, who were elected by popular vote. The canal commissioners had entire charge of the maintenance of the canals and the Portage Road.

A superintendent was elected from among their number, to have especial authority over the railroad.

The rails of the road were of iron weighing about twenty-five pounds to the foot and were secured to stone sleepers twenty inches square, which were sunk in the ground in parallel rows. The width between the rails was about six feet. Until some twenty-five years ago, stone sleepers were in use upon the New York, New Haven \& Hartford Railway, and were then removed on account of the especial wear and tear upon the rolling stock, which was avoided in the use of the more resilient, modern wooden

trous expedition of the British, under the leadership of the foolhardy Gen. Braddock, for the purpose of driving the French and Indians from Fort Duquesne, in the western extremity of the State. Several years after the States had gained their independence, the merging of Fort Duquesne into the settlement of Pittsburg suggested to the national government the advisability of an improved method of communication with this distributing point.

Accordingly, the Philadelphia-Pittsburg national pike was built upon such a substantial basis, that wherever undisturbed, as in the central part of the State, by the encroachment of "modern improvements," we still find the gracefully-modeled arches of solid masonry almost intact, after more than a century has passed. The completion of the Old Portage Railroad, by the State of Pennsylvania in 1834 , put an end to the time-honored "coach and six," with the many picturesque and commodious inns and taverns, along the line of this broad macadamized toll road; which in its substantial construction was, in point of endurance, tie. Few of the stone sleepers to-day remain embedded removed, recut, and utilized in the construction of public buildings in the nearby county seats. In this era of railway construction the modern iron and steel bridges were unknown. The crossing of streams and the national pikes was done by the construction of the substantial stone arches and culverts.

In 1845 to 1855 the construction of railway locomotives had reached such a stage of perfection, that it permitted the building of railroads ascending the mountain, by gradualy graded routes, entirely dispensing with the necessity of inclined planes with their stationary engines. And so the "New Portage" Railroad was built by the State, and contemporaneously. beginning in 1846 , a company of private individuals, linown as the Pennsylvania Railroad Company, was formed, stock issued, and the road laid along its pres. ent route. In 1854, after the rival lines had run for about two years, the Pennsylvania Railroad Company bought the New Portage Road from the State. Com

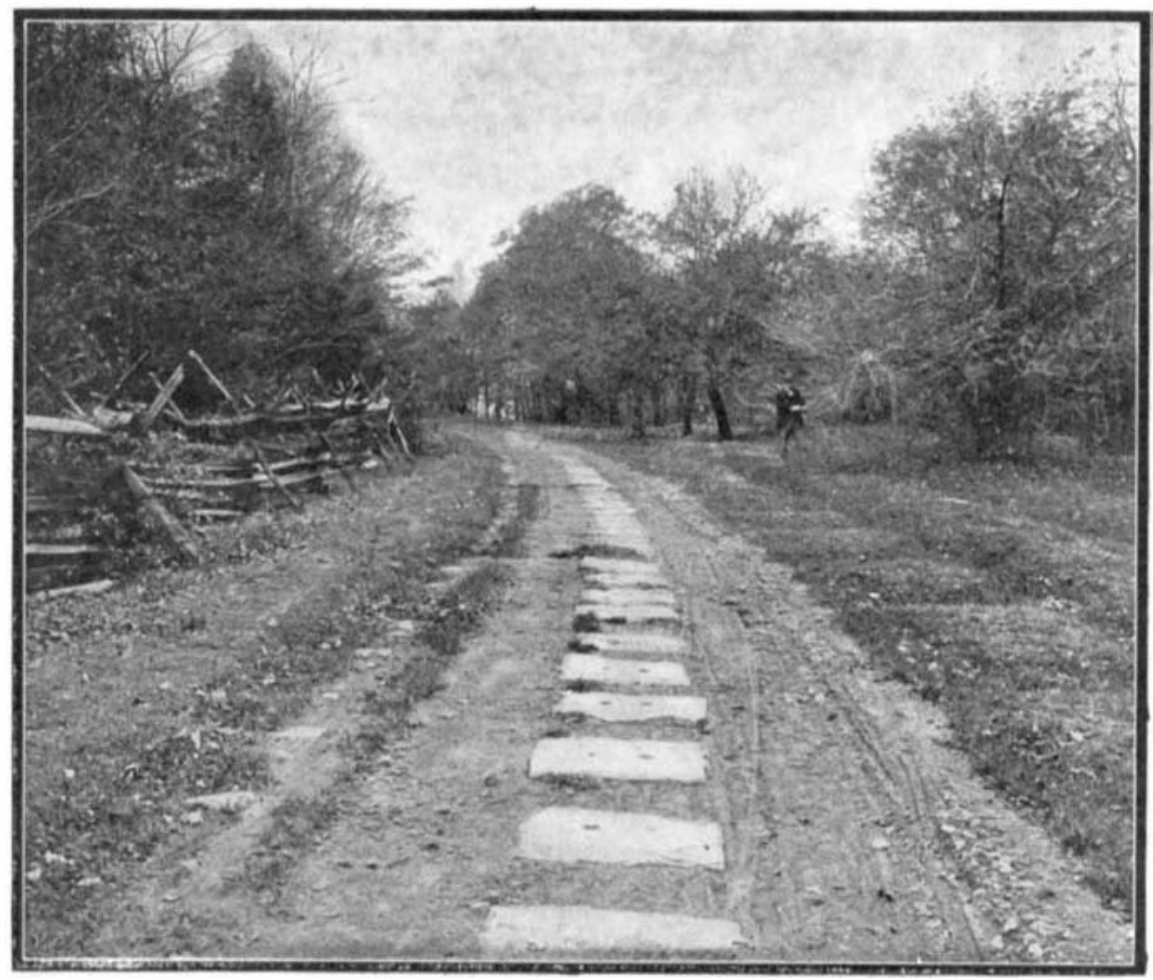

Photograpus copyrightsed 1902 by E. IT. L. Page.

SECTION OF OLD PORTAGE ROADBED, SHOWLNG DOUBLE ROWS OF STONE SLEEPERS

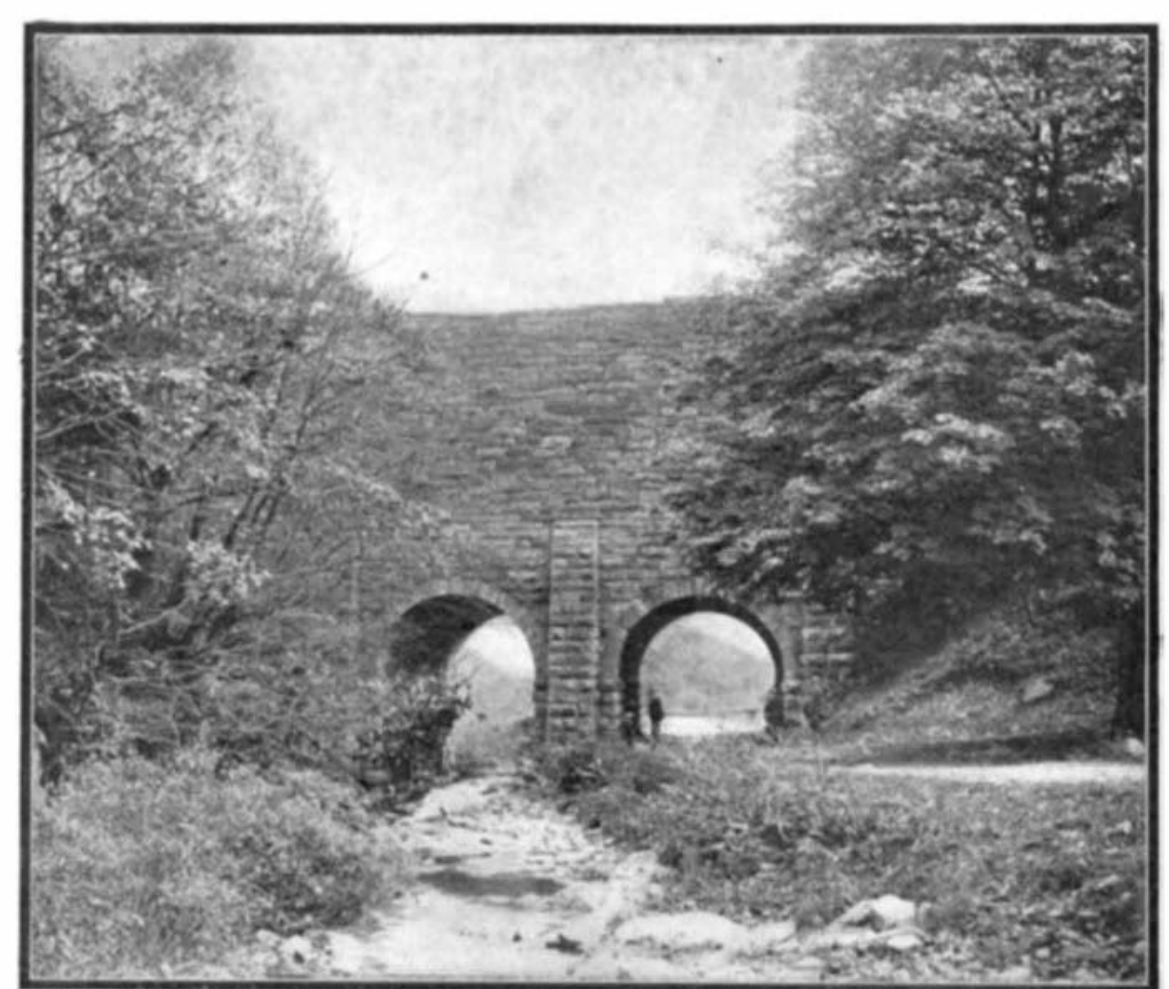

MASSIVE STONE CULVERT, RECENTLY DESTROYED. ERECTED IN 1848 ON THE LINE OF THE NEW PORTAGE RAILROAD. 

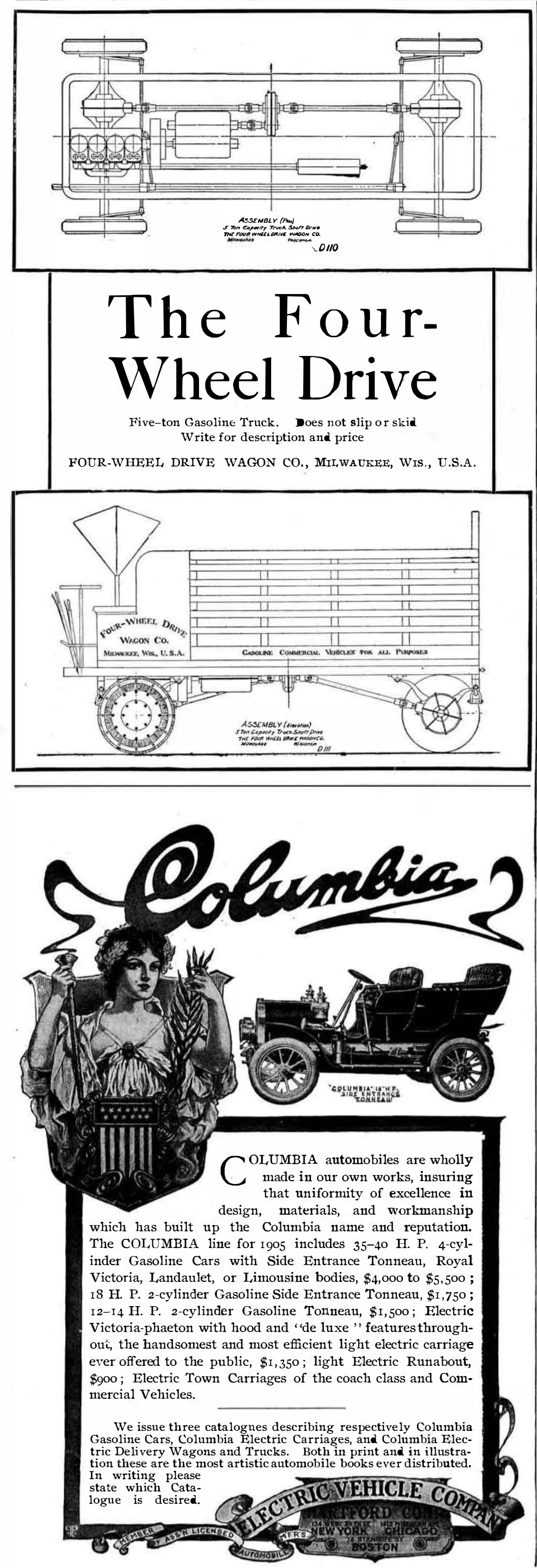

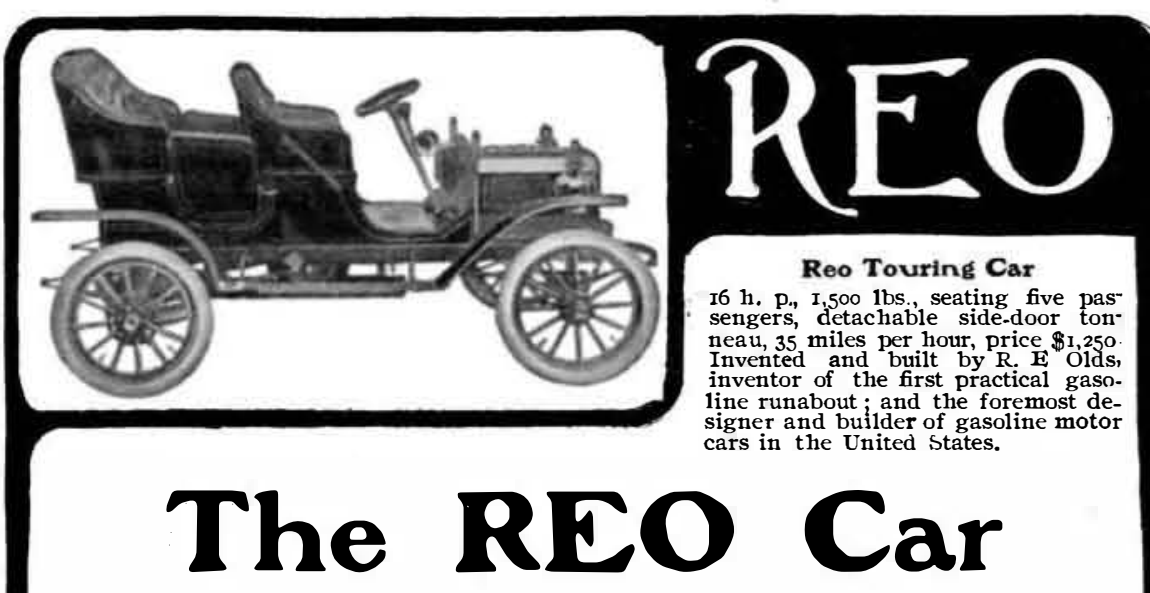

is

thoroughly right

Designed on right principles by a man who has studied those principles in every kind of motor engineering for a life-time.

Correctly applied as he has applied them for twenty years with con spicuous success.

Of enduring and practical construction, which extends to the smallest details and manifests itself brilliantly in the continuous speed and efficiency of actual use.

Luxurious in finish and appointments, in keeping with the most exacting demands of the present season.

Economical beyond any car of the day both in first cost and maintenance. Economical because correctly designed, simple and strong. Economical because built by a man sure of his car and his market, who built on a large scale and built right from the first.

Design, mechanics, construction, finish, price-all thoroughly right. Reo Runabout

8 H. P., 850 lbs., 25 miles per hour, price $\$ 650$

\section{The Reo Motor Car Co}

\section{R. M. Owens, Sales Manager}

Factory: LANSING, MICH. Sales Office: ${ }_{13} 8$ West 38 th St., NEW YORK Agents Throughout the United States

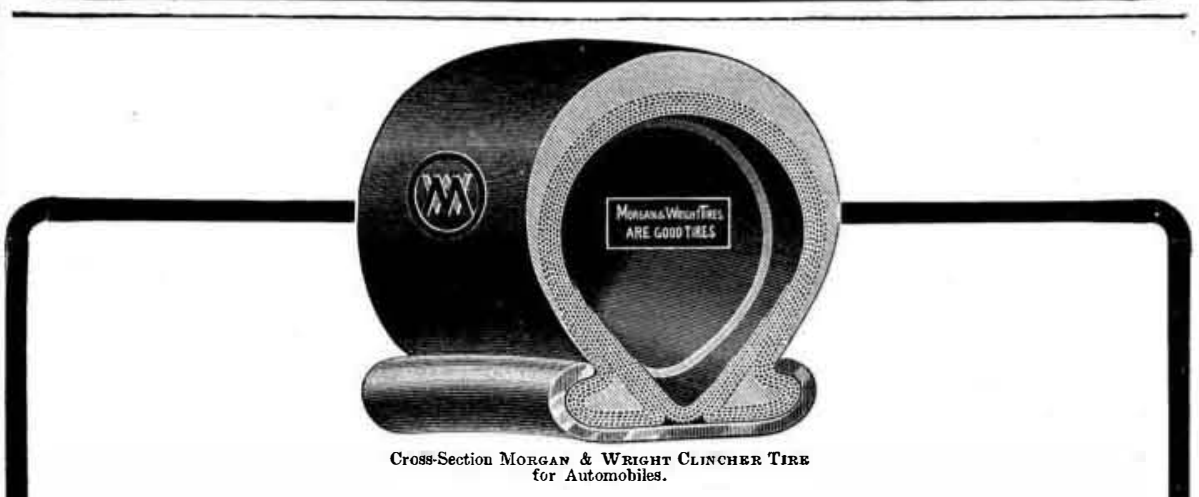

\section{THE VALUE OF PURE MATERIALS}

A dead tire is fit only for a corpse.
A real live man wants a real live tire-one that has plenty of elasticity - that grips the ground and makes a ride The resiliency of a tiredepends greatly on the material
of which it is made. Now, we don't make Morgan \& Wright Clincher Tires of scrap.

Lifeless, used-up materials that are chopped up and washed-not wholly cleaned.

A tire made from this "weary-worn" material will have its weak spots-will be constantly sick and ailing-will give you a melancholy, miserable ride! You will early re-

The Morgan \& Wright Clincher Tire FOR AUTOMOBILES

is full of life, resiliency, grip and vim

We make it from pure, crude Yara rubber-rubber that possesses the most resiliency of any rubber in the world. like iron. pure rubber. The whole tire is full of bounce and life and pure rubber

Then, to insure added wear, each Morgan \& Wright Clincher Tire is given an additional thickness of rubber on the tread (see diagram), which will not sofien, split, crack, or scale.

MORGAN \& WRIGHT, Chicago NEW YORK DAYTON DETROIT ATLANTA ST. LOUIS SAN FRANCISCO 
mon rumor says that at this time the State Legislature was "greased," and that not a cent of the $\$ 47,000,000$ which was to have been paid for the road was ever receive into the treasury of Pennsylvania; or as one visitor to this historic point writes: "Only another instance, by the way, to show the politicians of the present day are simply encroaching upon the methods of those of olden times." Immediately foliowing the charge of bribery upon the part of the railroad company, Pennsylvania turned from a Democratic into a Whig State.

The best time made on the Old Portage Road for the forty miles between Hollidaysburg and Johnstown was twelve hours. Express trains on the Pennsylvania Railroad now run a similar parallel distance over the Allegheny Mountains in a trifle over one hour. The passenger traffic on the road in those days was usually limite to one car each way a day, with a capacity of thirty people. The locomotives, as in the case of those in use in England to-day, had but little protection of the engineer and fireman. The passenger cars the engineer and fireman. The passenger cars scending the planes, an ingeniously constructed two-wheele safety car was attached in front of the train, and came automatically into service immediately upon the breaking of a cable. An old employe of the road states that serious accidents very rarely occurred. The inclined planes were operated by stationary engines of eighty horse-power each, located at the head of each plane. Double endless cables were used, made at first of hemp, three inches in diameter, and later of iron. In their mode of operation differing from the planes in use in Pittsburg and other hilly cities to-day the trains on those planes were each attached upon their arrival to the cable,

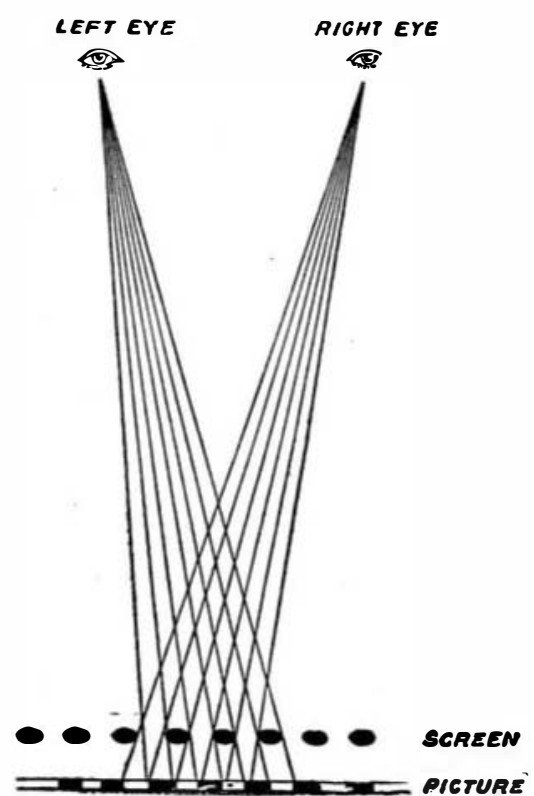

Diagram to Show How One Eye Sees One Series of Stripes While the Other Sees Only the other Series.

instead of being permanently connected with it. It required the work of an expert "hitcher" to attach the train with the cable by a short cable of great strength. The weight of the descending train was used to bal ance that of the one ascending, on double tracks. It is hardly necessary to say, in quoting the words of a present-day passenger conductor, that in the old Portage days there was no "running through Portage days there was no "running through midnight fogs at the terrific speed of 60 to 90
miles per hour." Then ten miles per hour was dreaded as "dangerous speed."

Many of the culverts along the line of the Old Portage Road were not built with the keystone for strength, as at the present day; but following the method of construction of the period, about 1800 , were built with the rows of stones running in a spiral form to give the required strength. In the photograph of the double stone culvert on the line of the New Portage Railroad, wilt in 1848 , it will be seen that the more modern keystone method of constructing stone arches is employed.

The Scientifir American en Route.

Regular readers of the ScIEntific AMERICAN will be gratified to note that some fifty express trains arriving or leaving New York daily carry the Scientific AMERICAN in the library or smoking cars. It will be found on the trains oi the New York Central and Hudson River Railroad, the Lake Shore Railroad, the "Big Four" Railroad, the Michigan Central Railroad, the Delaware, Lackawanna and Western Railroad, and the New York, New Haven and Hartford Railroad, The ScIEnTIFIC AMERICAN will also be found on seventy-five of the transatlantic and coastwise steamers, so that its regular readers will find it en route.
A PAVEMENT OF WHALES' BoNes, BY ABTHUR INKERSLEY.

One of the most picturesque towns in California or on the Pacific Slope is Monterey. Historically, it is the most interesting town in the Western States. It

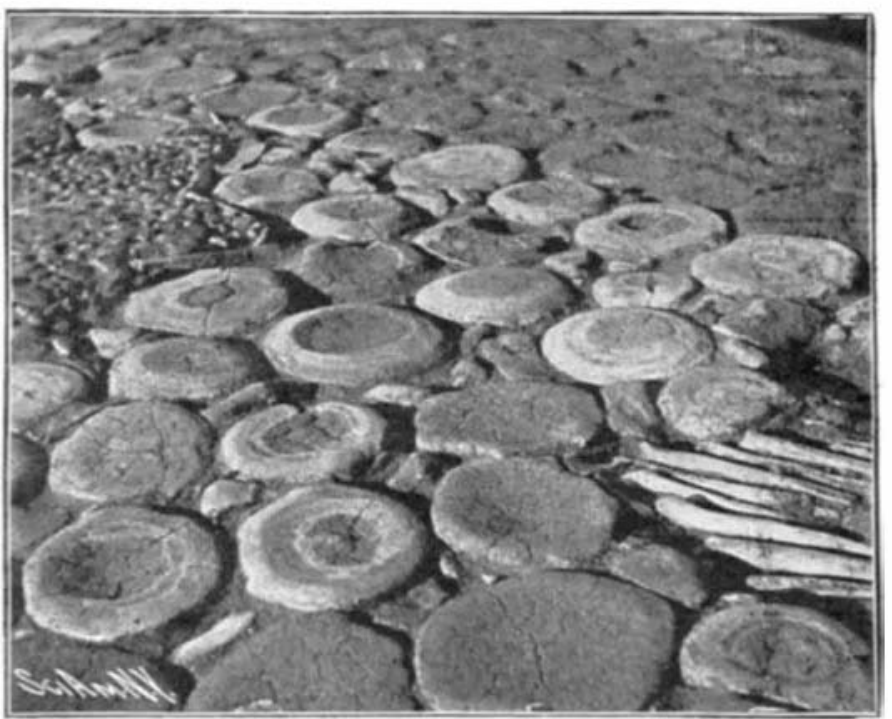

A PAVEMENT OF THE VERTEBR $\&$ AND BONES OF WHALES.

was the capital of Alta California when the Spanish held sway, in the days "before the Gringo came." Father Junipero Serra lande at Monterey, which is on the bay of the same name, on June 3,1770, more than six years before the signing of the Declaration of Independence. The missionary priest preached to the Indians and founded the mission church of San Carlos, which is still in excellent preservation. Many relics of Spanish rule are to be seen in Monterey, such as the old custom house, the jail, etc.

Besides being the capital of the Spanish province, Monterey was an important whaling station, many of those great mammals being found in Monterey Bay. The walk leading from the street to the main door of San Carlos mission church is pave with the vertebre and other bones of whales. The accompanying photograph, made at the end of August last, shows the com position and present condition of this remarkable pave ment.

\section{THE PARALLAX STEREOGRAM.}

An interesting method of obtaining a stereoscopic effect by means of a line screen is that known under the above title. By means of this invention, which we owe to Mr. F. Ives, the subject appears to stand out in high relief. The general principles involved arethese: Two photographs are first obtained by twin stereoscopic lenses, in the usual way, but interposed between the subject and the lenses is a screen of fine parallel lines. These lines are spaced by distances equal to their thickness, one-hundredth of an inch. Consequently, the negatives consist of a series of stripes, or rather of a number of long, excessively narrow photograph separated by blank spaces of exactly the same dimensions.

The negatives are now superposed so that the stripes left blank on one exactly coincide with the stripes of the other containing the picture. As can be seen from the accompanying illustration, the result is anythin but beautiful. The screen and picture, properly spaced, are mounted in a frame, which when held up to the

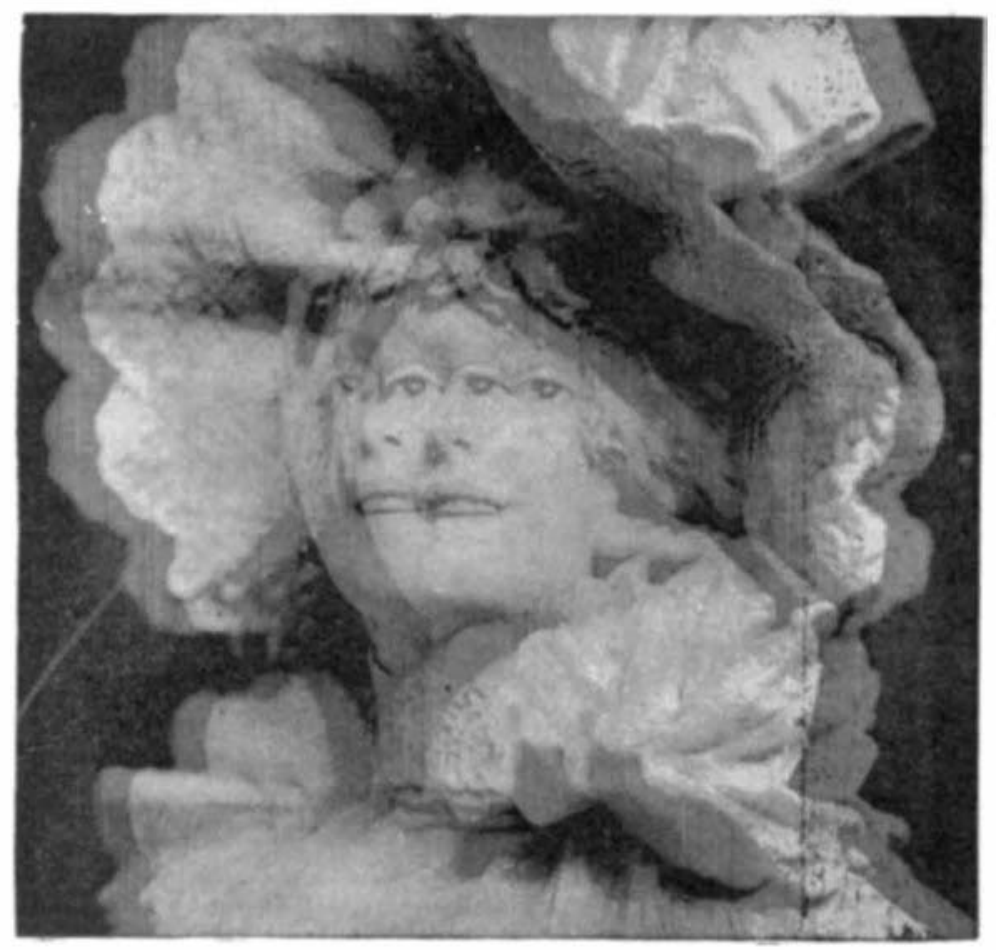

COMPOSITE PICTURE OF TWO STEREOSCOPIC VIEWS, EACH COVERING ALTERNATE STRIPES. light produces a most excellent stereoscopic effect. As the illustration shows, this is due to the fact that the right eye sees one picture and the left eye the other corresponding one. But these two images are superposed by the eye, and the result is a view in relief, due

to the angularity of the lines of sight from both eyes.

The Number of the Nebulæ.

Prof. Keeler, soon after beginning his programme of work with the Crossley reflector, showed that the number of nebulæ is very much greater than had been supposed. He conservatively place the number within reach of that telescope at one hundred and twenty thousand. His programme comprised the taking of photographs of one hundred and four of the brighter nebulæ and clusters located in all parts of the sky within reach of the telescope, i. e., north of declination -25 deg. The recent completion of this programme enables us to revise his estimate.

In fifty-seven of the regions seven hundred and forty-five new nebulæ have been discovered. Almost all of them are very small and faint. The regions in which no new ones were found were, as a rule, those surrounding the clusters and very large nebulæ. There were one hundred and forty-two known nebulæ in these regions, making the total number of nebulæ observed eight hund red and eighty-seven, an average of eight and onehalf per region. As it would take sixty-two thousand such photographs to cover the entire sky, the results ndicate five hundre thousand as the corresponding number of nebule within reach of the Crossley reflec-

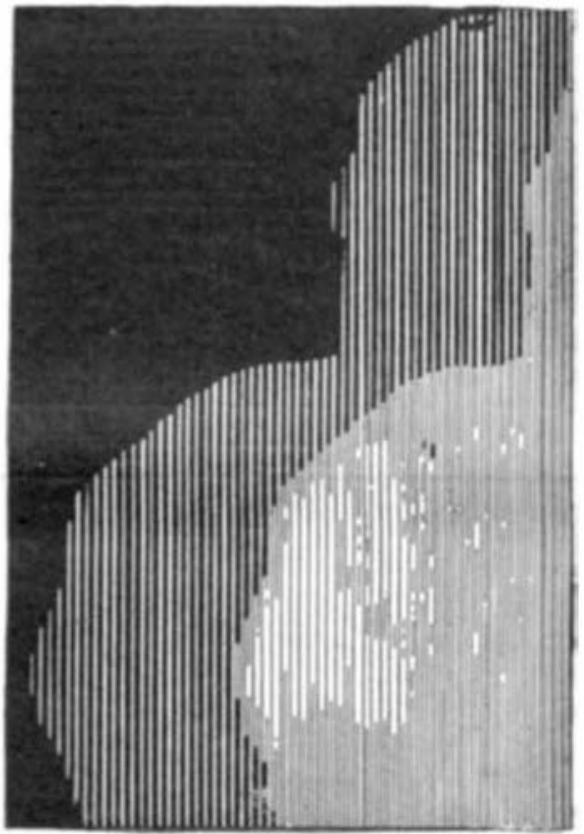

Portion of Picture (left-hand top corner) Enlarged to Show System of Stripes.

represents fairly the entire sky. It is well known that the nebule are much more numerous in some parts of the sky than in others. This is a tendency which, so far as we know, affects large and small nebulæ alike. The fact that a considerable number of other subjects than the nebulæ (presumably nonnebulous regions) are included in the programme, indicates that the portion observed is fairly representative of the whole sky.

Longer exposures, more sensitive plates, and more perfect photographs will undoubtedly re veal some nebulæ which do not now appear and others which are confuse with the faint stars. It seems probable, therefore, that the number of the nebulæ will ultimately be found to exceed a million.

The positions of the new nebulæ discovered on the Crossley photographs have been determined, and a catalogue of them will be printed in the volume of reproductions of nebulæ and clusters, soon to be issued. C. D. Perrine. Lick Observatory.

At the station in the southern hemisphere of the Lick Observatory, locate at Santiago de Chile, observations have been made during the past year of Alpha Centauri, and an average difference between the radial velocities of the two components is found of about 5.17 kilometers. This may perhaps be due to the relative orbital motion of the two components, and, if so, it would indicate a parallax of 0.76 , a combined mass of the components of 1.9 that of the sun; and a mean distance between th'e two components of $3.46 \times 10^{9}$ kilometers. The parallax thus indicated is almost precisely that resulting from heliometer observa. tions. 